Original research article

\title{
Quality of life of long-term surviving patients with colorectal carcinoma
}

\author{
Mária Šupínová *, Jana Lauková \\ Slovak Medical University in Bratislava, Faculty of Health Care in Banská Bystrica, Banská Bystrica, Slovak Republic
}

\begin{abstract}
Introduction: The number of long-term surviving patients with colorectal cancer (CRC) is growing. Their quality of life is rarely examined. Objective: The objective of this study was to assess health-related quality of life (HRQoL) in long-term surviving patients with CRC and determine demographic and clinical correlations that significantly affect HRQoL of the patients.

Methods: 162 long-term CRC survivors in the Slovak Republic were contacted through self-help groups. The condition for inclusion in the sample was at least three years of survival after diagnosis of CRC and termination of the treatment. The patients filled-in two questionnaires of the European Organisation for Research and Treatment of Cancer: QLQ-C30 and QLQ-CR 29.

Results: The analysis of the results shows statistically significant correlations between sex and Fatigue - SFA $(p=0.011)$ and Insomnia SL $(p=0.005)$. Significant correlations between age and Role functioning - RF2 $(p=0.041)$ and Nausea and vomiting $-\mathrm{NV}(p=0.011)$ have been shown. There are significant correlations between age and the following scales: Body image - BI $(p=0.023)$, Anxiety - ANX $(p=0.011)$, Sexual interest $-\operatorname{SEXF}(p=0.006)$, Financial difficulties - FI $(p=0.015)$ and Dyspareunia - DYS $(p=0.034)$. None of the scales correlate with disease duration.

Conclusions: The quality of life in the study group was not affected by the duration of survival. The quality of life scales are affected by age and sex of the respondents.
\end{abstract}

Keywords: Colorectal cancer; HRQoL QLQ-C30; Long-term surviving; Quality of life

\section{Introduction}

According to Marventano et al. (2013), colorectal cancer (CRC) is the third most commonly diagnosed cancer in men and the second in females - with a progressive increase in prevalence in industrialized countries. CRC has been found to be the second most common cancer and the second leading cause of cancer deaths in Europe (Ferlay et al., 2013).

Due to malignant disease of the colon and rectum, 4,406 operations were performed in Slovakia in 2017. Of these operations, a permanent ileostomy or colostomy was created in 1,149 patients (Health statistics, 2019). However, there was a slight decrease in the incidence and surgical treatment of colon malignancies compared to 2016 (a total of 4,839 cases).

Progress in screening, earlier detection and treatment, as well as aging populations, increase the survival rate of CRC (Faivre-Finn et al., 2002). Oncological disease and/or the consequences of treatment can lead to mental and functional impairment and changes in social survival. All of these factors affect health-related Quality of Life (QoL) (Marventano et al., 2013).
Some of these effects may persist after the treatment period and other problems may occur several years later (Caravati-Jouvenceaux et al., 2011).

Therefore, the quality of life of CRC survivors is endangered by ongoing health problems even years after the diagnosis and treatment (Bours et al., 2016).

Quality of life (QoL) is becoming an important assessment parameter in improving cancer treatment. It makes it possible to evaluate the impact of cancer and its treatment on patients' overall life (Mrabti et al., 2016).

Given the increasing number of long-term CRC survivors ( $\geq 5$ years after diagnosis), the long-term quality of life of the patients is very important (Eyl et al., 2018). According to Wong et al. (2013), the way of coping with a long-term disease also depends on the overall personality characteristics of the patient and the type and severity of the cancer.

According to Hart et al. (2018) and Caravati-Jouvenceaux et al. (2011) there is a lack of data on the physical functioning, mental well-being and quality of life of the surviving patients with colorectal cancer more than 10 years after the diagnosis.

In addition to mortality and morbidity, monitoring the quality of life of cancer patients is an important part of the

\footnotetext{
* Corresponding author: Mária Šupínová, Slovak Medical University in Bratislava, Faculty of Health Care in Banská Bystrica, Sládkovičova 21, 97405 Banská Bystrica, Slovak Republic; e-mail: maria.supinova@szu.sk http://doi.org/10.32725/kont.2020.027 
determinants of health in this population. Quality of life, as measured by the European Organization for Research and Treatment of Cancer (EORTC) QLQ-C30 and QLQ-CR29, will significantly improve the understanding of the quality of life of colorectal cancer survivors (Shen et al., 2018).

Also, according to Bours et al. (2016), such models are useful in clinical practice to identify CRC survivors who are at risk for deteriorated Health-Related Quality of Life (HRQoL). HRQoL information on long-term CRC survivors is important to assess the full spectrum of disease impact on the patients, their families and society (Caravati-Jouvenceaux et al., 2011).

The constancy or change in the quality of life depends on factors such as health, social security, personality, lifestyle, etc., that can be modified to improve quality of life. The quality of life must be evaluated from the perspective of various correlations that are comparable to the hierarchy of human needs. These correlations include abilities and factors such as: independence, self-sufficiency, decision-making ability, absence of pain and suffering, retention of sensory abilities, maintaining a social support system, a certain financial standard, a sense of usefulness for others, a degree of happiness, etc. (Janiczeková, et al., 2016; Zacharová and Haluzíková, 2013).

The objective of this study was to assess health-related quality of life (HRQoL) in long-term surviving patients with CRC and identify demographic and clinical correlations that significantly affect HRQoL of the patients.

\section{Methods and methods}

\section{Study design}

The study is a retrospective cross-sectional questionnaire survey of patients with $C R C$. A generic localized and standardized EORTC QLQ-C30 (version 3) module for cancer patients and a localized CRC-specific QLQ-CR29 module were used in the study. The Slovak version of the questionnaire and consent to its use was provided by EORTC.

The combination of a generic cancer core questionnaire and a specific module provides an effective way of measuring the quality of life with excellent sensitivity and specificity, which in turn will facilitate and improve comprehensive research on results (Shen et al., 2018). The questionnaire does not investigate the presence of comorbidity that may affect QoL. Separate modules (e.g. for different time periods after diagnosis or treatment) do not yet exist (Martijn et al., 2016). Non-specificity of the time period - focus is evaluated as a limiting point of the questionnaire.

Patients with malignant colon disease, surviving more than 3 years after diagnosis of the disease and termination of the treatment, were selected. Participation in the group was voluntary and anonymous, without giving any personal information.

In Slovakia, the exact number of long-term surviving patients after the diagnosis of CRC is not recorded and therefore not known. For this reason, it is a problem to contact them. Many of them are ashamed of colostomy and are not involved in the activities of self-help groups, or groups of patients with the same diagnosis. Nor can we exclude the possibility that patients with the worst quality of life and relapse do not engage in the self-help groups and have not responded to the questionnaire survey.

Data collection started in 2018 through self-help groups SLOVILCO and ILCO that join together CRC patients in Slo- vakia. A package was sent to selected patients containing (1) a cover letter indicating the study objective and explanatory instructions, signed by the author of the study (2) EORTC QLQ-C30 and QLQ-C29 questionnaires in the Slovak version (3) a stamped return envelope. A total of 250 questionnaires were sent out with a return rate of 213 questionnaires (85.2\%). Questionnaires from patients with a disease duration of less than 12 months (18 questionnaires $7.2 \%$ ) were excluded from the group. A total of 162 questionnaires were included in the group. The EORTC Quality of Life Questionnaire Core 30 (QLQ-C30) evaluates QoL with 30 items measuring 15 dimensions: global health scale, five functional scales (physical, daily activity, cognitive, emotional and social), three symptom scales (fatigue, pain and nausea/vomiting) and six single-item scales measuring symptoms or problems (dyspnoe, insomnia, loss of appetite, constipation, diarrhea and financial difficulties).

The quality of life values were not determined according to the level of education, marital status, cancer localization or stage of the disease. Surviving patients with CRC for more than 3 years after diagnosis and treatment ( $\geq 3$ years after diagnosis and treatment), depending on age, sex, survival from diagnosis and treatment, were studied. The average duration of the respondents' illness at the time of the research was $12.22 \pm 7.6$ years.

A total of 162 respondents (65 women and 97 men) were included in the sample. The mean age of the whole group was $66.87 \pm 9.25$ years. The mean age of the women was $65.94 \pm$ 10.94 , the mean age of the men was $67.49 \pm 7.92$.

The Quality of Life Questionnaire (EORTC) in Colorectal Cancer Module QLQ-CR29 must always follow QLQ-C30. It evaluates QoL with 29 items measuring 2 scales: Functional scales: Body Image, Anxiety, Weight, Sexual interest. Symptom scales: Urinary frequency, Blood and mucus in stool, Stool frequency, Urinary incontinence, Dysuria, Abdominal pain, Buttock pain, Bloating, Dry mouth, Hair loss, Taste, Flatulence, Faecal incontinence, Sore skin, Embarrassment, Stoma care problems, Impotence, Dyspareunia.

\section{Results}

Descriptive statistics of the scales of both instruments (QLQ-C29 and QLQ-C30) are presented in Table 1 and Table 2.

Table 1 shows the descriptive statistics for the QLQ-C30 questionnaire. In 6 domains, a higher score means better performance, the opposite is true for scales and separate passwords for symptoms. The evaluation of QoL reaches an average value (sQL2). As reported by the respondents, the most annoying were fatigue (FA), abdominal pain (PA) and insomnia (SL).

Table 2 shows the descriptive statistics for the QLQ-C29 questionnaire. In both domains and passwords for symptoms, a higher score means worse performance. In two separate domains of sexuality, SEXM indicates the value of Sexual interest in men and SEXF Sexual interest in women. The worst rated domains were physical appearance (BI), sexual interest (SEX$\mathrm{M} / \mathrm{W}$ ), weight (WEI) and anxiety (ANX).

The effect of sex on the scoring in the scales is shown in Table 3. The effect of sex on Fatigue - SFA $(p=0.011)$ and Insomnia - SL $(p=0.005)$ is statistically significant at significance level $\alpha=0.05$. The scales and their impact on quality of life were rated worse by women. 
Table 1. Descriptive statistics of QLQ-C30 scales

\begin{tabular}{|c|c|c|c|c|c|c|}
\hline & $n$ & $\mathrm{~d}$ & sd & median & $\min$ & $\max$ \\
\hline sQL2 & 162 & 52.5 & 23.6 & 50.0 & 0.0 & 100.0 \\
\hline sPF2 & 162 & 72.8 & 19.0 & 76.7 & 20.0 & 100.0 \\
\hline sRF2 & 162 & 67.1 & 26.1 & 66.7 & 0.0 & 100.0 \\
\hline sEF & 162 & 76.0 & 22.4 & 83.3 & 0.0 & 100.0 \\
\hline $\mathrm{SCF}$ & 162 & 78.5 & 20.3 & 83.3 & 0.0 & 100.0 \\
\hline $\mathrm{sSF}$ & 162 & 67.8 & 26.9 & 66.7 & 0.0 & 100.0 \\
\hline sFA & 162 & 38.0 & 24.8 & 33.3 & 0.0 & 100.0 \\
\hline sNV & 162 & 14.2 & 21.5 & 0.0 & 0.0 & 100.0 \\
\hline sPA & 162 & 32.6 & 26.9 & 33.3 & 0.0 & 100.0 \\
\hline sDY & 162 & 26.7 & 26.2 & 33.3 & 0.0 & 100.0 \\
\hline sSL & 162 & 38.7 & 32.4 & 33.3 & 0.0 & 100.0 \\
\hline sAP & 162 & 18.1 & 25.8 & 0.0 & 0.0 & 100.0 \\
\hline sCO & 162 & 14.6 & 25.2 & 0.0 & 0.0 & 100.0 \\
\hline sDI & 162 & 23.0 & 29.1 & 0.0 & 0.0 & 100.0 \\
\hline sFI & 162 & 33.5 & 31.6 & 33.3 & 0.0 & 100.0 \\
\hline
\end{tabular}

Legend: $\mathrm{d}$ - mean; sd - standard deviation; min, $\max$ - minimum value and maximum value in the cohort.

Global health status / QoL: QL2 - Global health status / QoL (revised). Functional scales: F2 - Physical functioning (revised), RF2 - Role functioning (revised), EF - Emotional functioning; CF - Cognitive functioning; SF - Social functioning. Symptom scales/items: FA - Fatigue; NV - Nausea and vomiting; PA - Pain; DY - Dyspnoea; SL - Insomnia; AP - Appetite loss; CO - Constipation; DI - Diarrhoea; FI - Financial difficulties.

Table 2. Descriptive statistics of QLQ-C29 scales

\begin{tabular}{|c|c|c|c|c|c|c|}
\hline & $n$ & d & sd & median & $\min$ & $\max$ \\
\hline sBI & 162 & 65.8 & 27.1 & 66.7 & 0.0 & 100.0 \\
\hline sANX & 162 & 63.0 & 30.2 & 66.7 & 0.0 & 100.0 \\
\hline sWEI & 162 & 73.9 & 26.7 & 66.7 & 0.0 & 100.0 \\
\hline sSEXM & 95 & 61.8 & 30.0 & 66.7 & 0.0 & 100.0 \\
\hline sSEXF & 60 & 83.3 & 24.2 & 100.0 & 0.0 & 100.0 \\
\hline sUF & 162 & 44.7 & 24.5 & 50.0 & 0.0 & 100.0 \\
\hline sBMS & 162 & 5.9 & 11.7 & 0.0 & 0.0 & 66.7 \\
\hline sSF_yes & 138 & 21.4 & 21.9 & 16.7 & 0.0 & 100.0 \\
\hline sSF_no & 24 & 16.0 & 18.7 & 16.7 & 0.0 & 83.3 \\
\hline sUI & 162 & 21.4 & 26.4 & 0.0 & 0.0 & 100.0 \\
\hline sDY & 162 & 8.2 & 19.7 & 0.0 & 0.0 & 100.0 \\
\hline sAP & 162 & 20.8 & 24.9 & 0.0 & 0.0 & 100.0 \\
\hline sBP & 162 & 13.2 & 22.4 & 0.0 & 0.0 & 100.0 \\
\hline sBF & 162 & 24.1 & 25.0 & 33.3 & 0.0 & 100.0 \\
\hline sDM & 162 & 23.5 & 25.2 & 33.3 & 0.0 & 100.0 \\
\hline sHL & 162 & 14.6 & 27.3 & 0.0 & 0.0 & 100.0 \\
\hline sTA & 162 & 16.9 & 24.1 & 0.0 & 0.0 & 100.0 \\
\hline sFL_yes & 138 & 30.7 & 29.6 & 33.3 & 0.0 & 100.0 \\
\hline sFL_no & 24 & 16.7 & 17.0 & 16.7 & 0.0 & 33.3 \\
\hline sFI_yes & 138 & 25.1 & 26.4 & 33.3 & 0.0 & 100.0 \\
\hline sFI_no & 24 & 12.5 & 21.6 & 0.0 & 0.0 & 66.7 \\
\hline sSS_yes & 138 & 29.0 & 29.0 & 33.3 & 0.0 & 100.0 \\
\hline sSS_no & 24 & 18.1 & 24.0 & 0.0 & 0.0 & 100.0 \\
\hline sFI_yes & 138 & 41.1 & 29.1 & 33.3 & 0.0 & 100.0 \\
\hline sFI_no & 24 & 13.9 & 19.5 & 0.0 & 0.0 & 66.7 \\
\hline
\end{tabular}


Table 2. (Continued)

\begin{tabular}{|c|c|c|c|c|c|c|}
\hline & $n$ & $d$ & sd & median & $\min$ & $\max$ \\
\hline sSTO & 140 & 21.2 & 25.4 & 0.0 & 0.0 & 100.0 \\
\hline sIMP & 94 & 43.6 & 34.2 & 33.3 & 0.0 & 100.0 \\
\hline sDYS & 52 & 15.4 & 27.6 & 0.0 & 0.0 & 100.0 \\
\hline
\end{tabular}

Legend: $\mathrm{d}$ - mean; sd - standard deviation; $\min , \max$ - minimum value and maximum value in the cohort.

Functional scales: BI - Body Image; ANX - Anxiety; WEI - Weight; SEXM - Sexual interest (men); SEXW - Sexual interest (women).

Symptom scales: UF - Urinary frequency; BMS - Blood and mucus in stool; SF - Stool frequency; UI - Urinary incontinence; DY - Dysuria; AP - Abdominal pain; BP - Buttock pain; BF - Bloating; DM - Dry mouth; HL - Hair loss; TA - Taste; FL - Flatulence; FI - Faecal incontinence; Sore SS - skin; EMB - Embarrassment; STO - Stoma care problems; IMP - Impotence; DYS - Dyspareunia.

\section{Table 3. Test results - the effect of sex on QLQ-C30 scales}

\begin{tabular}{lcc} 
& $Z_{\text {adj }}$ & $P$ \\
\hline sQL2 & 0.610 & 0.542 \\
sPF2 & -0.733 & 0.464 \\
sRF2 & 0.536 & 0.592 \\
sEF & -0.586 & 0.558 \\
sCF & 0.754 & 0.451 \\
sSF & 0.232 & 0.816 \\
sFA & 2.541 & 0.011 \\
sNV & -0.840 & 0.401 \\
sPA & 1.419 & 0.156 \\
sDY & -0.048 & 0.962 \\
sSL & 2.814 & 0.005 \\
sAP & -0.602 & 0.548 \\
sCO & -0.188 & 0.851 \\
sDI & 0.373 & 0.709 \\
sFI & -1.213 & 0.225 \\
\hline
\end{tabular}

Legend: Test statistics $\left(\mathrm{Z}_{\text {adj }}\right)$ Mann-Whitney test; $\alpha=0.05$.
Table 4 shows the results of the correlation analysis between age and disease duration on scales with a non-parametric Spearman correlation coefficient $[R(S)]$ and an appropriate probability value $(P)$. There are significant correlations between age and Role functioning - RF2 $(p=0.041)$ and Nausea and vomiting - NV $(p=0.011)$. The value of RF2 scale increases with age, which means better rating of the scale by older respondents, while the NV scale decreases with age. This means that the scale of nausea and vomiting was rated better by older respondents. None of the scales correlate with disease duration.

The effect of sex on Dysuria - DY $(p=0.026)$ and Hair loss - HL ( $p=0.048)$ is statistically significant at a significance level of 0.05 . The mean value of dysuria is higher in men (more annoying), while hair loss is higher and represents a heavier burden for women (Table 5).

Table 6 shows the Spearman correlation coefficient $[R(S)]$ and the probability value $(P)$ test results. There are significant correlations between age and the scales: Body image $-\mathrm{BI}$ $(p=0.023)$, Anxiety - ANX ( $p=0.011)$, Sex interest - SEXF $(p=0.006)$, Financial difficulties - FI $(p=0.015)$ (for those who answer yes to question 18) and Dyspareunia - DYS ( $p=0.034)$. None of the scales correlate with disease duration. The values of BI, ANX and SEXF scales increase with age, while EMB and DYS decrease with age.

Table 4. Test results - the effect of age and disease duration on QLQ-C30 scales

\begin{tabular}{lccccc} 
& & & Age & \multicolumn{2}{c}{ Disease duration } \\
\hline sQL2 & $n$ & $\mathrm{R}(\mathrm{S})$ & $P$ & $\mathrm{R}(\mathrm{S})$ & 0.036 \\
sPF2 & 162 & 0.047 & 0.555 & -0.115 & 0.648 \\
sRF2 & 162 & 0.028 & 0.723 & 0.003 & 0.146 \\
sEF & 162 & 0.161 & $\mathbf{0 . 0 4 1}$ & -0.040 & 0.968 \\
sCF & 162 & 0.131 & 0.097 & -0.026 & 0.136 \\
sSF & 162 & 0.033 & 0.676 & 0.005 & 0.085 \\
sFA & 162 & 0.107 & 0.152 & -0.045 & 0.954 \\
sNV & 162 & -0.113 & $\mathbf{0 . 0 1 1}$ & 0.009 & 0.566 \\
sPA & 162 & -0.200 & 0.998 & 0.033 & 0.906 \\
sDY & 162 & 0.000 & 0.298 & -0.043 & 0.676 \\
sSL & 162 & -0.082 & 0.225 & 0.022 & 0.589 \\
sAP & 162 & -0.096 & 0.369 & -0.096 & 0.784 \\
sCO & 162 & -0.071 & 0.143 & -0.045 & 0.020
\end{tabular}

Legend: Test statistics: Spearman correlation coefficient $[\mathrm{R}(\mathrm{S})]$; probability $(P) ; \alpha=0.05$. 
Table 5. Test results - the effect of sex on QLQ-C29 scales

\begin{tabular}{|c|c|c|}
\hline & $Z_{\text {adj }}$ & $P$ \\
\hline sBI & -0.176 & 0.860 \\
\hline sANX & -0.800 & 0.424 \\
\hline sWEI & -1.211 & 0.226 \\
\hline sUF & -1.469 & 0.142 \\
\hline sBMS & 0.782 & 0.434 \\
\hline sSF_yes & -0.315 & 0.753 \\
\hline sSF_no & -0.279 & 0.780 \\
\hline sUI & 0.163 & 0.871 \\
\hline sDY & 2.224 & 0.026 \\
\hline sAP & -0.161 & 0.872 \\
\hline$s B P$ & 0.829 & 0.407 \\
\hline $\mathrm{sBF}$ & -1.324 & 0.186 \\
\hline sDM & -1.778 & 0.075 \\
\hline sHL & -1.974 & 0.048 \\
\hline sTA & -0.296 & 0.767 \\
\hline sFL_yes & 0.093 & 0.926 \\
\hline sFL_no & -1.203 & 0.229 \\
\hline sFI_yes & 0.019 & 0.985 \\
\hline sFI_no & 0.654 & 0.513 \\
\hline sSS_yes & -0.426 & 0.670 \\
\hline sSS_no & -0.957 & 0.338 \\
\hline sFI_yes & -0.737 & 0.461 \\
\hline sFI_no & 0.853 & 0.393 \\
\hline sSTO & 1.236 & 0.217 \\
\hline \multicolumn{3}{|l|}{ sIMP } \\
\hline \multicolumn{3}{|c|}{$\begin{array}{l}\text { Legend: Test statistics }\left(\mathrm{Z}_{\text {adj }}\right) \text { Mann-Whitney test; } \alpha=0.05 \text {. } \\
\text { Functional scales: BI - Body Image; ANX - Anxiety; WEI - Weight; } \\
\text { SEXM - Sexual interest (men); SEXW - Sexual interest (women). } \\
\text { Symptom scales: UF - Urinary frequency; BMS - Blood and mucus in } \\
\text { stool; SF - Stool frequency; UI - Urinary incontinence; DY - Dysuria; } \\
\text { AP - Abdominal pain; BP - Buttock pain; BF - Bloating; DM - Dry } \\
\text { mouth; HL - Hair loss; TA - Taste; FL - Flatulence; FI - Faecal } \\
\text { incontinence; SS - Sore skin; EMB - Embarrassment; STO - Stoma } \\
\text { care problems; IMP - Impotence; DYS - Dyspareunia. }\end{array}$} \\
\hline
\end{tabular}

Chart 1 shows the evaluation of dysuria and hair loss, depending on the sex of the respondents. Dysuria affected men's quality of life more, while hair loss affected women's more.
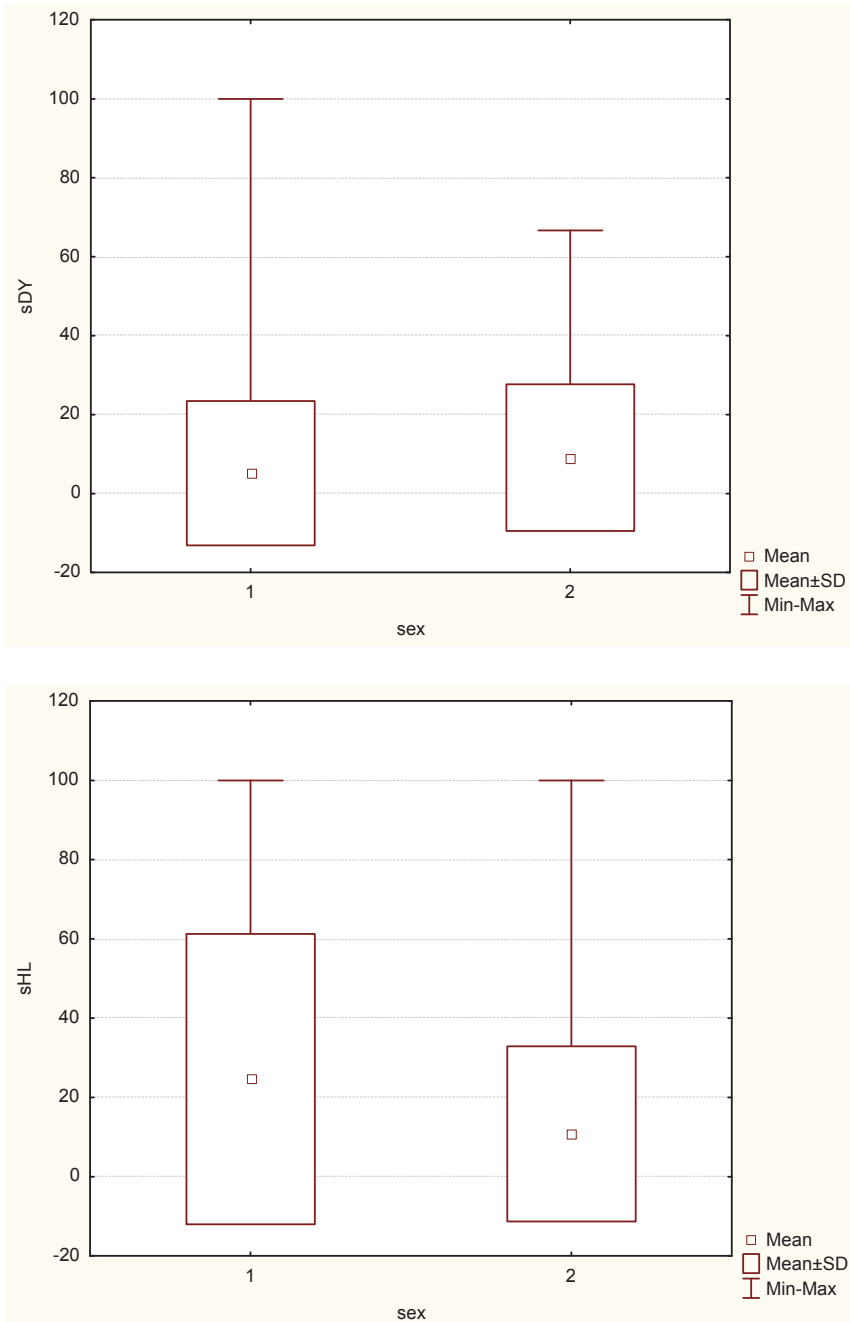

Legend: DY - Dysuria; HL - Hair loss.

Chart 1. Graphical representation of the mean values of significant scales DY and SHL for women (1) and men (2)

Table 6. Test results - the effect of age and disease duration on QLQ-C29 scales

\begin{tabular}{|c|c|c|c|c|c|}
\hline & & \multicolumn{2}{|c|}{ Age } & \multicolumn{2}{|c|}{ Disease duration } \\
\hline sBI & 162 & 0.178 & 0.023 & -0.019 & 0.807 \\
\hline sANX & 162 & 0.200 & 0.011 & 0.102 & 0.196 \\
\hline sWEI & 162 & 0.142 & 0.072 & 0.014 & 0.863 \\
\hline sSEXM & 95 & 0.095 & 0.361 & -0.160 & 0.122 \\
\hline sSEXF & 60 & 0.351 & 0.006 & 0.245 & 0.059 \\
\hline sUF & 162 & -0.033 & 0.677 & 0.044 & 0.581 \\
\hline sBMS & 162 & -0.090 & 0.255 & 0.028 & 0.721 \\
\hline sSF_yes & 138 & -0.115 & 0.179 & -0.031 & 0.714 \\
\hline sSF_no & 24 & -0.397 & 0.055 & 0.121 & 0.573 \\
\hline sUI & 162 & 0.005 & 0.948 & 0.133 & 0.091 \\
\hline sDY & 162 & -0.068 & 0.393 & -0.013 & 0.871 \\
\hline sAP & 162 & -0.142 & 0.072 & -0.065 & 0.408 \\
\hline
\end{tabular}


Table 6. (Continued)

\begin{tabular}{|c|c|c|c|c|c|}
\hline \multirow[b]{2}{*}{ sBP } & \multirow[b]{2}{*}{162} & \multicolumn{2}{|c|}{ Age } & \multicolumn{2}{|c|}{ Disease duration } \\
\hline & & 0.024 & 0.760 & -0.005 & 0.946 \\
\hline sBF & 162 & -0.079 & 0.319 & 0.009 & 0.913 \\
\hline sDM & 162 & 0.089 & 0.261 & 0.066 & 0.406 \\
\hline sHL & 162 & -0.147 & 0.062 & -0.047 & 0.549 \\
\hline sTA & 162 & -0.112 & 0.157 & -0.054 & 0.498 \\
\hline sFL_yes & 138 & 0.042 & 0.624 & 0.159 & 0.063 \\
\hline sFL_no & 24 & 0.000 & 1.000 & 0.244 & 0.251 \\
\hline sFI_yes & 138 & -0.055 & 0.525 & 0.101 & 0.238 \\
\hline sFI_no & 24 & -0.125 & 0.560 & -0.123 & 0.568 \\
\hline sSS_yes & 138 & -0.111 & 0.193 & 0.036 & 0.678 \\
\hline sSS_no & 24 & 0.141 & 0.511 & -0.209 & 0.326 \\
\hline sFI_yes & 138 & -0.207 & 0.015 & -0.034 & 0.690 \\
\hline sFI_no & 24 & -0.275 & 0.194 & -0.086 & 0.690 \\
\hline sSTO & 140 & 0.036 & 0.676 & 0.001 & 0.991 \\
\hline sIMP & 94 & -0.019 & 0.854 & -0.035 & 0.737 \\
\hline sDYS & 52 & -0.295 & 0.034 & -0.202 & 0.152 \\
\hline
\end{tabular}

Chart 2 shows the incidence of fatigue and insomnia, depending on the respondents' sex. The mean values of both

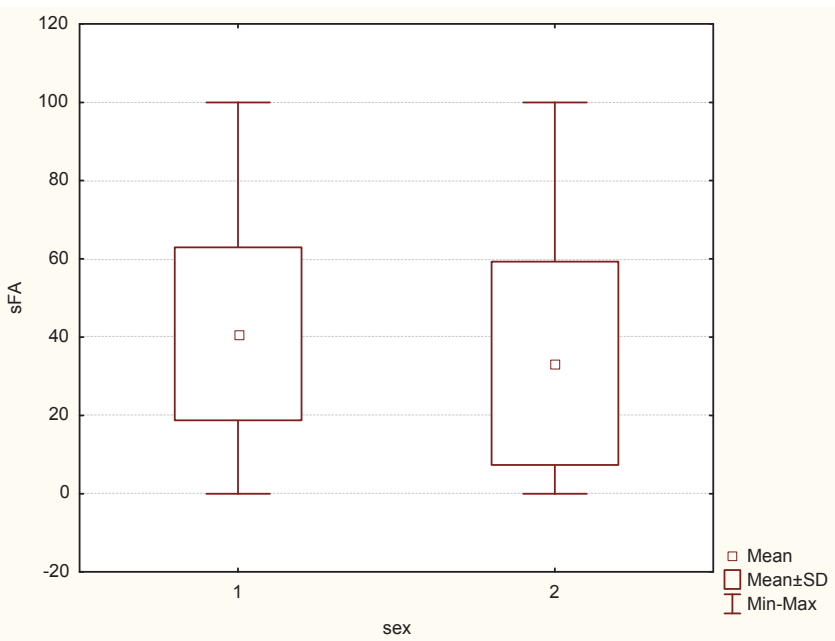

scales reach lower values in men. Worse ratings of the scales, and a worse impact on QoL, were found in the group of women.

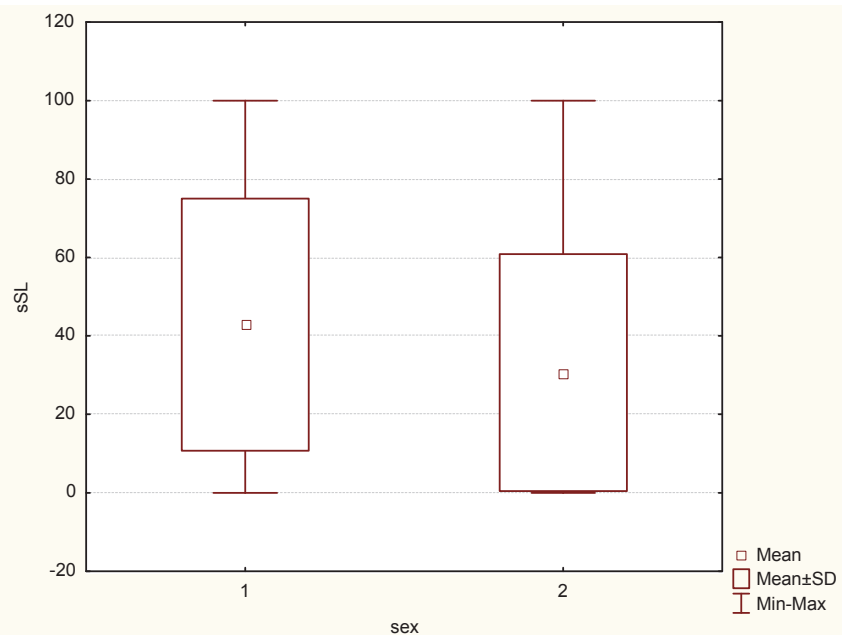

Legend: FA - Fatigue; SL - Insomnia.

Chart 2. Graphical representation of the mean values of significant scales FA and SL for women (1) and men (2).

\section{Discussion}

The population of long-term surviving patients with colorectal cancer $(C R C)$ is growing, and many of them experience an impaired health-related quality of life (HRQoL) in the early and late stages after treatment (Bours et al., 2016).

However, those who achieve long-term remission from colorectal cancer may experience a relatively high QoL, although physical symptoms such as diarrhea and depressive symptoms remain (Ramsey et al., 2002).
The research found that long-term CRC survivors evaluate the areas of quality of life, despite the persistence of some negative symptoms, as satisfactory (Table 1,2 ). Also, the results of the study by Caravati-Jouvenceaux et al. (2011) show that QoL appears to be generally satisfactory, compared to population standards, in CRC survivors who regard themselves as cured (without relapse or metastasis $\geq 5$ years after diagnosis) and in patients 15 years after diagnosis. Also, according to Ramsey et al. (2002), long-term survivors reported a higher general QoL, but had a higher incidence of depression and chronic recurrent diarrhea. Bowel dysfunction may still be a problem 
15 years after the diagnosis of CRC. However, some cancer complications may persist $\geq 10$ years after the diagnosis, e.g. stool problems, fatigue and social relationship problems (Caravati-Jouvenceaux et al., 2011). The loss of energy, the feeling of fatigue, the high proportion of anxiety and sleep disorders were significantly demonstrated in relation to the gender in our research. In women, the evaluation results were worse (Table 5, Chart 2). The effect of gender on Dysuria and Hair loss was statistically demonstrated. Dysuria lowered men's quality of life ratings. Hair loss negatively affected women's quality of life more (Chart 1).

The length of survival of respondents after treatment with CRC is not a decisive factor affecting their quality of life, nor is the presence of stoma. The dominant criterion affecting the values of the scales of quality of life questionnaires is the sex of patients (Table 3 ) and their age (Table 4). Stoma may not be the most influential factor worsening QoL, according to the study results (Rauch et al., 2004). Stoma patients unexpectedly reported significantly better social functioning than non-stoma patients, with less anxiety and higher self-esteem. The results did not show any difference between stoma and non-stoma patients in body image, future perspective or sexual life. Abdominal or pelvic pain and constipation had the most negative effect on QoL (Rauch et al., 2004). The scale of abdominal or pelvic pain also reached relatively high values in our group of respondents.

Significant correlations were demonstrated between age and body image, age and anxiety, age and sexual interest, age and financial difficulties and dyspareunia, which worsen the quality of life of younger age groups of respondents. The scales of Role functioning and Nausea and vomiting are also related to age in favour of older respondents (Table 6). Younger patients, stoma patients and those suffering from diarrhea or constipation are more likely to report poor health-related quality of life in a six-week follow-up (Wilson et al., 2006).

In another study, most long-term CRC survivors with resected colon carcinoma who have been disease-free for 5 years reported problems with energy deficiency, sexual functioning and bowel disorders (Phipps et al., 2008).

It has been found that psychosocial interventions can improve the quality of life of patients with CRC. Before using them, it is important to assess the physical functioning or severity of the symptoms (Son et al., 2018).

The results of Alacacioglu et al. (2010) show a strong correlation between anxiety and depression and poor quality of life in Turkish colorectal cancer patients.
Different conclusions came from a study that also examined the quality of life of long-term CRC survivors; it showed that social QoL and depression are not serious problems for long-term CRC survivors (Hart et al., 2018).

People who have survived colon and rectal cancer appear to have a comparable quality of life and, in some areas, have better well-being than the healthy population. The correlation between respondents' quality of life and disease duration was not confirmed. According to Hart et al. (2018), a good quality of life can also be expected in the group of long-term survivors. Overall, physical activity is associated with improved QoL in patients who have survived CRC. There is conclusive evidence that physical activity (PA), especially leisure time PA, is associated with improved overall survival in CRC patients. Therefore, it could be beneficial for long-term CRC survivors to be physically active (Eyl et al., 2018).

\section{Conclusions}

In oncology, the number of long-term surviving and cured patients is growing. These are patients after surgery, chemotherapy and/or radiotherapy. They underwent treatment - in childhood, early adulthood and later. The objective of the research was to monitor the quality of life of patients suffering from chronic illness and, subsequently, to recommend the direction of interventions to improve their quality of life. Patients who are ill and who accept this condition may change their plans and expectations after the period necessary for adaptation to the disease. They adapt to life with disease and thus regain a sense of well-being.

According to our findings, the duration of the disease has no significant effect on any of the quality of life scales. Age, sex of patients and persistent symptomatology are important factors affecting several quality of life scales.

The role of nursing staff, especially nurses with higher education, is to support the patient in adaptation efforts and help them in finding new horizons in life. It is important to optimize the long-term follow-up of QoL in cured patients in order not to deteriorate the quality of life through excessive investigation and to detect early signs of late toxicity.

\section{Conflict of interests}

The authors have no conflict of interests to declare.

\section{Kvalita života dlhodobo prežívajúcich pacientov s kolorektálnym karcinómom}

Súhrn

Úvod: Počet dlhodobo prežívajúcich pacientov s rakovinou hrubého čreva a konečníka (CRC), sa zvyšuje. Kvalita ich života je len zriedka predmetom skúmania.

Ciel': Ciel'om štúdie bolo vyhodnotit' kvalitu života súvisiacu so zdravím (HRQOL) u pacientov dlhodobo prežívajúcich s CRC a určit' demografické a klinické korelácie, ktoré významne ovplyvňujú HRQOL pacientov.

Metódy: Bolo oslovených 162 dlhodobo prežívajúcich pacientov s CRC v SR, prostredníctvom svojpomocných skupín. Podmienkou pre zaradenie do súboru bolo minimálne trojročné prežívanie po stanovení diagnózy CRC a ukončení liečby. Pacienti vyplnili dva dotazníky European Organisation for Research and Treatment of Cancer QLQ-C30 a QLQ-CR 29.

Výsledky: Z analýzy výsledkov vyplývajú štatisticky významné korelácie vplyvu pohlavia a škál únava - SFA $(p=0,011)$ a insomnia - SL $(p=0,005)$. Boli dokázané významné korelácie vplyvu veku a škály fungovanie role - RF2 $(p=0,041)$ a nauzea a vomitus - NV ( $p=0,011)$. Významné korelácie s vekom majú škály Body image - BI $(p=0,023)$, Anxiety - ANX $(p=0,011)$, Sexualita $-\operatorname{SEXF}(p=0,006)$, finančné tažkosti $-\operatorname{EMB}(p=0,015)$ a bolest' pri pohlavnom styku - DYS $(p=0,034)$. S dížkou ochorenia žiadna zo škál nekoreluje.

Záver: Kvalita života v sledovanej skupine účastníkov štúdie nebola ovplyvnená dížkou prežívania. Škály kvality života sú ovplyvňované vekom a pohlavím respondentov.

Kl'účové slová: dlhodobo prežívajúci; HRQoL QLQ-C30; kvalita života; rakovina hrubého čreva a konečníka 


\section{References}

1. Alacacioglu A, Binicier O, Gungor O, Oztop I, Dirioz M, Yilmaz U (2010). Quality of life, anxiety, and depression in Turkish colorectal cancer patients. Support Care Cancer 18(4): 417-21. DOI: 10.1007/s00520-009-0679-2.

2. Bours MJ, Van der Linden BW, Winkels RM, Van Duijnhoven FJ, Mols F, Van Roekel EH, et al. (2016). Candidate Predictors of Health-Related Quality of Life of Colorectal Cancer Survivors: A Systematic Review. Oncologist 21(4): 433-452. DOI: 10.1634/ theoncologist.2015-0258.

3. Caravati-Jouvenceaux A, Launoy G, Klein D, Henry-Amar M, Abeilard E, Danzon A, et al. (2011). Health-related quality of life among long-term survivors of colorectal cancer: A populationbased study. Oncologist 16(11): 1626-1636. DOI: 10.1634/ theoncologist.2011-0036.

4. Eyl RE, Xie K, Koch-Gallenkamp L, Brenner H, Arndt V (2018). Quality of life and physical activity in long-term ( $\geq 5$ years post-diagnosis) colorectal cancer survivors - systematic review. Health Qual Life Out Comes 16: 112. DOI: 10.1186/s12955018-0934-7.

5. Faivre-Finn C, Bouvier-Benhamiche AM, Phelip JM, Manfredi S, Dancourt V, Faivre J (2002). Colon cancer in France: evidence for improvement in management and survival. Gut 51(1): 60-64. DOI: 10.1136/gut.51.1.60.

6. Ferlay J, Steliarova-Foucher E, Lortet-Tieulent J, Rosso S, Coebergh JWW, Comber H, et al. (2013). Cancer incidence and mortality patterns in Europe: estimates for 40 countries in 2012. Eur J Cancer 49: 1374-1403. DOI: 10.1016/j. ejca.2012.12.027.

7. Hart TL, Charles ST, Gunaratne M, Baxter NN, Cotterchio M, Cohen Z, Gallinger S (2018). Symptom Severity and Quality of Life Among Long-term Colorectal Cancer Survivors Compared With Matched Control Subjects: A Population-Based Study. Dis Colon Rectum 61(3): 355-363. DOI: 10.1097/ DCR.0000000000000972.

8. Health statistics [Zdravotnícka štatistika] (2019). Chirurgická a jednodňová starostlivost' v r. 2017. Národné centrum zdravotníckych informácií. Bratislava. [online] [cit. 201910-15]. Available from: http://www.nczisk.sk/Documents/ publikacie/2017/zs1810.pd (Czech).

9. Janiczeková E, et al. (2016). Výskum efektivity intravenózneho aplikovania vitamínu C z hl'adiska ovplyvnenie kvality života onkologických pacientov. In: Sborník př́ispěvků z X. mezinárodního sympozia ošetřovatelství. Ostrava 26. 5. 2016. Ostrava: Ostravská univerzita, Lékařská fakulta.
10. Martijn JL, Van der Linden BWA, Winkels RM, Van Duijnhoven FJ, Mols F, Van Roekel EH, et al. (2016). Candidate Predictors of Health-Related Quality of Life of Colorectal Cancer Survivors: A Systematic Review. Oncologist 21(4): 433-452. DOI: 10.1634/theoncologist.2015-0258.

11. Marventano S, Forjaz MJ, Grosso G, Mistretta A, Giorgianni G, Platania A, et al. (2013). Health related quality of life in colorectal cancer patients: state of the art. BMC Surg 13 (Suppl. 2): S15. DOI: 10.1186/1471-2482-13-S2-S15.

12. Mrabti H, Amziren M, El Ghissassi I, Bensouda Y, Berrada N, Abahssain H, et al. (2016). Quality of life of early stage colorectal cancer patients in Morocco. BMC Gastroenterol 16: 131. DOI: 10.1186/s12876-016-0538-9.

13. Phipps E, Braitman LE, Stites S, Leighton JC (2008). Quality of life and symptom attribution in long-term colon cancer survivors. J Eval Clin Prac. 14(2): 254-258. DOI: 10.1111/j.1365-2753.2007.00842.x.

14. Ramsey SD, Berry K, Moinpour C, Giedzinska A, Andersen MR (2002). Quality of life in long term survivors of colorectal cancer. Am J Gastroenterol 97(5):1228-1234. DOI: 10.1111/j.1572-0241.2002.05694.x.

15. Rauch P, Miny J, Conroy T, Neyton L, Guillemin F (2004). Quality of life among disease-free survivors of rectal cancer. J Clin Oncol 22(2): 354-360. DOI:10.1200/JCO.2004.03.137.

16. Shen MH, Chen LP, Ho TF, Shih YY, Huang CS, Chie WC, Huang CC (2018). Validation of the Taiwan Chinese version of the EORTC QLQ-CR29 to assess quality of life in colorectal cancer patients. BMC Cancer 18: 353. DOI: 10.1186/s12885018-4312-y.

17. Son H, Son YJ, Hyerang K, Yoonju L (2018). Effect of psychosocial interventions on the quality of life of patients with colorectal cancer: a systematic review and meta-analysis. Health Qual Life Outcomes 16: 119. DOI: 10.1186/s12955-0180943-6.

18. Wilson TR, Alexander DJ, Kind P (2006). Measurement of health-related quality of life in the early follow-up of colon and rectal cancer. Dis Colon Rectum 49(11): 1692-1702. DOI: 10.1007/s10350-006-0709-9.

19. Wong CK, Lam CL, Poon JT, Kwong DL (2013). Clinical Correlates of Health Preference and Generic Health-Related Quality of Life in Patients with Colorectal Neoplasms. PLoS One 8(3): e58341. DOI: 10.1371/journal.pone.0058341.

20. Zacharová E, Haluzíková J (2013). Bolest a její zvládání v ošetřovatelské péči. Interní Med 15(11-12): 272-274. 